\title{
Protein and lipid deposition rates in growing pigs following a period of excess fattening
}

\author{
N. S. Ferguson ${ }^{\#}$ and B.K. Theeruth \\ Animal and Poultry Science, School of Agricultural Sciences and Agribusiness, University of Natal, Private Bag X01, \\ Scottsville 3209, South Africa.
}

\begin{abstract}
The objective of this experiment was to test the proposition that fatter pigs, when fed a high crude protein (CP) diet, would attempt to correct the effects of excess fattening on body composition by returning to a state that is consistent with pigs grown under non-limiting nutritional conditions. The experiment was divided into two phases: Phase 1 was from 15 to $30 \mathrm{~kg}$ in which 72 of the 96 Large White $\mathrm{x}$ Landrace $\mathrm{x}$ Duroc pigs (equal male and female) were made fatter by consuming a low CP food (LP1) (181 g/kg (as fed)). The remaining 24 pigs were fed a high CP food (HP1) $(223 \mathrm{~g} / \mathrm{kg}$ (as fed)) to provide the rate and composition of growth associated with unrestricted or normal growth. Phase 2 was the rehabilitation phase and was divided into two periods: 30 to $45 \mathrm{~kg}$ and 45 to $60 \mathrm{~kg}$. Pigs that were fed LP1 were randomly allocated to one of a high CP (HP2) (204 g/kg (as fed)), low CP (LP2) (159 g/kg (as fed)) or medium CP (MP2) (181 g/kg (as fed)) food, respectively. Pigs fed HP1 in Phase 1 continued to be fed HP2 in Phase 2. During Phase 1, pigs fed HP1 consumed less food but grew at a similar rate to pigs fed LP1. Pigs fed LP1 were significantly fatter, had less body water and had a higher lipid:protein ratio $(0.86 \pm 0.04 v s .0 .67 \pm 0.09 \mathrm{~g} / \mathrm{g}$, respectively) at the end of Phase 1 . Between 30 and $45 \mathrm{~kg}$, pigs fed HP2 and previously fed LP1, retained significantly less lipid and had the lowest lipid growth:protein growth ratio $(0.38 \pm 0.05)$ than all other treatments. By 45 and $60 \mathrm{~kg}$, there were no significant differences in the lipid content and lipid:protein ratio of pigs across all treatments. It can be concluded that nutritionally induced, fat pigs will attempt to restore their body lipid contents, to those levels in animals not previously nutritionally deprived, by reducing their rate of lipid retention when fed a higher crude protein food.
\end{abstract}

Keywords: Protein growth, lipid growth, growing pigs.

\# Corresponding author. E-mail: ferguson@nu.ac.za

\section{Introduction}

It has been widely accepted that an animal has an inherent potential rate of protein deposition (Kielanowski, 1969; Whittemore et al., 1988; Moughan, 1999; Schinckel, 2001), but little consideration has been given to the possibility that animals also have a desired (target) rate of lipid deposition. Emmans (1981) first alluded to the concept of a 'desired lipid growth' to quantify the relationship between protein and lipid growth and voluntary food intake. In subsequent papers (Kyriazakis \& Emmans, 1991; Kyriazakis et al., 1991; Kyriazakis \& Emmans, 1992), the authors provided evidence for the idea that pigs, which are fatter than normal (as defined by animals grown under non-limiting conditions), will attempt to correct this deviation once the limiting condition has been removed. Whittemore (1998) also refered to this desired level of fatness (or 'target fat') as a means of explaining the minimum amount of lipid relative to protein that a growing pig can deposit. The difference between quantifying the potential growth rate of protein and the desired rate of lipid retention, is that protein has an upper limit set by its potential, whereas such appears not the case for lipid (Wilson \& Osbourn, 1960; Campbell \& Biden, 1978; Tullis \& Whittemore, 1986; Emmans \& Kyriazakis, 1999). This can be observed, for example, in pigs fed protein-limiting foods who gain lipid at a much faster rate than pigs fed a protein-adequate food, in an attempt to achieve its potential protein growth rate (Kyriazakis et al., 1991; Ferguson \& Gous, 1997).

When a growing animal such as a young pig is placed under a nutritional limitation, such as being fed an imbalanced food or food intake is restricted for a period of time, it will fail to grow as fast as it can, or its body gain will be of abnormal composition, or both (Campbell \& Dunkin, 1983; Stamataris et al., 1991; Kyriazakis et al., 1991). The body composition at the end of a period of nutritionally limited growth may see the animal having a protein deficit together with either a lipid deficit or lipid excess in its empty body. According to 
Kyriazakis \& Emmans (1992), the rate of lipid deposition is dependent on the rate at which an animal attempts to return to its normal protein weight in a non-limiting environment. If the animal has both a protein and lipid deficit, then the correction of one usually assists the other. An attempt to overcome a protein deficit will usually result in an increased food intake and a consequential increase in lipid retention rates due to the over consumption of energy (Kyriazakis \& Emmans, 1991; Ferguson \& Gous, 1997; Ferguson et al., 2000). Experimental evidence indicates that animals which are fatter than their desired level, show a reduction in lipid gain, once the dietary protein deficiency is removed (Kyraizakis \& Emmans, 1991; Kyriazakis et al., 1991; Stamataris et al., 1991). It is proposed that this response will continue until the level of fatness has returned to levels similar to those observed in animals that have been unrestricted or followed normal growth.

The objective of this experiment was to test the postulations of Kyriazakis \& Emmans (1992) that fatter pigs, when fed a high crude protein (CP) food would attempt to correct the effects of excess fattening on body composition by returning to a state that is consistent with the growth of an animal under non-limiting conditions or normal growth. To aid this purpose, young pigs were fed a food low in CP to induce high rates of lipid retention. It was anticipated that pigs, previously fed a low CP food, would deposit less fat and / or grow protein at a faster rate and restore the lipid:protein weight ratio of their empty body to the normal value. This response presupposes that the lipid:protein growth rate ratio will decrease towards a minimum value, when fed a higher CP food.

\section{Materials and Method}

One hundred crossbred Large White x Landrace x Duroc pigs (48 entire males and 52 females) were obtained at eight weeks of age and housed in open-sided, group pens. On arrival four female pigs with a mean live weight of $15.4 \pm 0.08 \mathrm{~kg}$ were slaughtered to provide the chemical composition of the empty body weight (EBW) of pigs at the start of the experiment. This also balanced the sex ratio and group structure. The remaining 96 pigs with a mean live weight of $13.5 \pm 2.77 \mathrm{~kg}$ were fed a commercial high CP $\operatorname{diet}(24 \% \mathrm{CP}, 14.5 \mathrm{MJ} \mathrm{DE} / \mathrm{kg})$ for three days where after they were randomly assigned to one of 12 pens. Each pen contained one large plastic feed bin (Big Dutchman Lean Machine ${ }^{\circledR}$ ) in the centre of the pen with two nipple drinkers and two food dispensing structures activated by touch. An additional nipple drinker was provided on the side of each pen. These facilities allowed for free and continuous access to food and water for all pigs.

Two foods per phase were formulated to contain similar energy contents but with one diet having a higher CP concentration than the other (Table 1). The high CP foods (HP1 and HP2) were formulated to be in excess of CP requirements during the respective periods while the low CP feeds (LP1 and LP2) were to be deficient in protein. Estimates of CP requirements were based on the dietary protein concentrations $(200 \mathrm{~g} / \mathrm{kg}$, Phase 1; $180 \mathrm{~g} / \mathrm{kg}$, Phase 2) that produced the optimum response from previous studies conducted with this genotype (Ferguson \& Gous, 1997; Ferguson et al., 2000; Ferguson et al., 2001). Dietary amino acids were balanced according to the ideal protein balance, with lysine as the reference amino acid (Wang \& Fuller, 1989). Phase 1 foods (HP1 and LP1) were pelletized. Phase 2 foods (HP2 and LP2) were in the form of a mash with the medium CP (MP2) consisting of a blend of equal proportions of high CP (HP2) and low CP (LP2) foods (Table 1). All foods were intended to be non-limiting in energy, minerals and vitamins.

To accommodate the change in nutrient requirements between 15 to $60 \mathrm{~kg}$ live weight, the experiment was divided into two phases. In Phase 1 (15 to $30 \mathrm{~kg}$ ) three pens were allocated to the high CP food (HP1) and the remaining nine pens to the low CP food (LP1). Eight pigs were allocated to each pen. Of the pigs fed HP1, one pen was allocated to females and two pens to males. Similarly four pens were allocated to males fed LP1 and the remaining five to females. The objective was to create two groups of pigs with different body lipid weights. Pigs fed LP1 were expected to have higher body lipid contents whilst pigs fed HP1 were to have a desired (or normal) level of protein and lipid that was indicative of their genetic potential. At the end of Phase 1, two female and two male pigs fed HP1, and seven pigs (three females and four males) fed LP1 were randomly selected and slaughtered. Phase 1 foods were replaced by Phase 2 foods (HP2, LP2, MP2) and changed from pellet to mash once the average pen weight reached $30 \mathrm{~kg}$. At the start of Phase 2, the nine pens with pigs fed LP1 in Phase 1 were reassigned; three pens each were allocated to provide pigs with one of HP2, LP2 or MP2 foods respectively. Pigs fed HP1 continued to be fed HP2 for the duration of Phase 2. Phase 2 comprised two periods: 30 to $45 \mathrm{~kg}$ and 45 to $60 \mathrm{~kg}$, and ended once the pigs in the pen reached a mean live weight of $60 \mathrm{~kg}$. 
Within Phase 2, 16 pigs were slaughtered at both $45 \mathrm{~kg}$ and $60 \mathrm{~kg}$ live weight to determine rates of protein and lipid retention between 30 to $45 \mathrm{~kg}$, and 45 to $60 \mathrm{~kg}$. Two male and two female pigs per treatment were selected for slaughter. Those selected were closest to the target weight when the average weight of the pen was either 45 or $60 \mathrm{~kg}$. This ensured that there were four pigs from each of the treatments including pigs fed HP1-HP2, LP1HP2, LP1-MP2 and LP1-LP2 to be analysed for chemical composition.

Table 1 The ingredient and chemical composition ( $\mathrm{g} / \mathrm{kg}$ fresh weight) of the high (HP1) and low (LP1) protein foods offered in Phase 1 (15 to $30 \mathrm{~kg}$ live weight) and the high (HP2), medium (MP2) and low (LP2) protein foods offered in Phase 2 (30-60 kg live weight)

\begin{tabular}{|c|c|c|c|c|c|}
\hline \multirow[b]{2}{*}{ Ingredients } & \multicolumn{2}{|c|}{ Phase $1(15-30 \mathrm{~kg})$} & \multicolumn{3}{|c|}{ Phase $2(30-60 \mathrm{~kg})$} \\
\hline & HP1 & LP1 & HP2 & $\mathrm{MP}^{*}$ & LP2 \\
\hline Yellow maize & 432.0 & 538.9 & 347.0 & 414.8 & 482.5 \\
\hline Maize germ & & & 150.0 & 95.0 & 40.0 \\
\hline Fullfat soya & 200.0 & 200.0 & 200.0 & 200.0 & 200.0 \\
\hline Fish meal & 135.3 & 31.0 & & & \\
\hline Wheat middlings & 133.5 & 116.5 & 60.3 & 105.2 & 150.0 \\
\hline Soyabean oilcake & 50.0 & 50.0 & 143.0 & 93.2 & 43.3 \\
\hline Molasses & 30.0 & 30.0 & 30.0 & 40.0 & 49.9 \\
\hline Sunflower oilcake & & & 30.0 & 30.0 & \\
\hline Limestone & 7.5 & 121.5 & 19.3 & 19.6 & 19.9 \\
\hline Lysine $\mathrm{HCl}$ & 3.5 & 3.1 & 4.6 & 4.6 & \\
\hline Vitamin and mineral premix & 3.0 & 3.0 & 2.0 & 2.0 & 2.0 \\
\hline Monocalcium phosphate & 2.3 & 10.8 & 7.3 & 6.8 & 6.3 \\
\hline Methionine DL & 1.6 & 0.4 & 1.1 & 1.1 & \\
\hline Salt & 1.0 & 3.5 & 4.5 & 4.7 & 4.9 \\
\hline Choline chloride & 0.3 & 0.3 & 0.3 & 0.3 & 0.3 \\
\hline \multicolumn{6}{|l|}{ Analysed Composition: } \\
\hline Digestible Energy $(\mathrm{MJ} / \mathrm{kg})^{\dagger}$ & 14.0 & 14.1 & 13.4 & 13.3 & 13.1 \\
\hline $\mathrm{CP}(\mathrm{Nx} 6.25)(\mathrm{g} / \mathrm{kg})$ & 223 & 181 & 204 & 181 & 159 \\
\hline \multicolumn{6}{|c|}{ Calculated Total amino acid $(\mathrm{g} / \mathrm{kg})$ : } \\
\hline Lysine & 14.6 & 10.0 & 12.0 & 10.0 & 7.9 \\
\hline Methionine + Cysteine & 9.1 & 6.1 & 7.4 & 6.2 & 4.9 \\
\hline Threonine & 9.2 & 6.7 & 7.8 & 6.5 & 5.2 \\
\hline Tryptophan & 2.7 & 2.1 & 2.4 & 2.0 & 1.5 \\
\hline
\end{tabular}

The pigs were weighed weekly and food was checked daily. Food weighed in, was recorded and each time a pig was removed the food was weighed out. Phase 1 slaughter pigs were weighed and killed by an injection of pentobarbitol sodium once they had achieved approximate $30 \mathrm{~kg}$ live weight. The whole dead body of the pig was placed in a plastic bag and sealed to chill at $0{ }^{\circ} \mathrm{C}$ overnight. The stomach and intestines were then removed and weighed full, stripped of their contents and weighed empty. The emptied stomach and intestines were added to the carcass weight to provide an estimate of the empty body weight. The viscera and carcass was cut into smaller pieces and placed into a mincer, homogenized and subsampled for chemical analysis. Phase 2 pigs were killed by exsanguination at a commercial abattoir when they had attained their respective slaughter live weights (45 or $60 \mathrm{~kg}$ ). After being stunned, the blood was collected in a plastic bag. The pigs were eviscerated and the gastrointestinal tract, bladder, heart, liver and lungs were removed. Each empty carcass was halved along the midline, with the right half of the carcass being chosen for further analyses. The half carcass, organs and blood were stored overnight at $0{ }^{\circ} \mathrm{C}$ in a sealed plastic bag. The contents of the stomach and 
intestines were emptied. The half carcass was portioned and stored in a sealed plastic bag and frozen at $-20^{\circ} \mathrm{C}$. Similarly, the empty gastrointestinal tract, remaining organs and blood were combined and stored in a separate bag. The combined organs and blood were homogenized and then halved by weight. The frozen carcass portions and half the combined blood and organs were homogenized in a mincer. Samples were then collected in duplicate from each pig and used in the laboratory for proximate analysis according to AOAC (1984) methods, except for lipid which was calculated from the gross energy and CP content according to the method described by Ferguson et al. (2000). The duplicated results were combined to provide a single result for each pig. The dry matter content of each sample was determined by freeze drying the samples for $48 \mathrm{~h}$. The ash content was determined by burning in a muffle furnace at $550^{\circ} \mathrm{C}$ overnight, while the $\mathrm{CP}$ content was calculated as nitrogen $\mathrm{x}$ 6.25, where nitrogen content of the dry matter was determined on a LECO nitrogen analyser (LECO Africa (Pty) Limited, P.O. Box 1439, Kempton Park, South Africa).

Pigs to be slaughtered for estimating empty body composition at 30,45 and $60 \mathrm{~kg}$, were randomly selected at the start of the trial. The pigs were slaughtered on attaining their designated live weight and the time taken to reach this weight was recorded for each individual pig. For Phase 1 the chemical composition of the initial slaughter group was used to estimate the proportions of protein and lipid in the EBW at $15 \mathrm{~kg}$ live weight of the animals slaughtered at $30 \mathrm{~kg}$. The rates of retention were determined by subtracting the component weight at $15 \mathrm{~kg}$ from the component weight at $30 \mathrm{~kg}$ and dividing by the time taken to grow between the two weights. Similarly for Phase 2 the component weights at 30, 45 and $60 \mathrm{~kg}$ live weights and the respective times taken, were used to determine the rates of protein and lipid retention between $30-45 \mathrm{~kg}$ and $45-60 \mathrm{~kg}$. Starting composition of the EBW at $30 \mathrm{~kg}$ live weight of animals slaughtered at $45 \mathrm{~kg}$ was derived from the proportion of EBW calculated at $30 \mathrm{~kg}$. Similarly, for animals slaughtered at $60 \mathrm{~kg}$, the EBW composition at $45 \mathrm{~kg}$ was used to determine their starting component weights.

At the end of Phase 1 all pigs were compared with their mean pen weight with the aim of removing individuals that were at least two standard deviations above or below the mean pen weight. This was done to maintain pen uniformity. No pigs were found to be more than two standard deviations above the pen mean weight but eight animals weighed less than two standard deviations below the mean pen weight. This resulted in four females and three males fed LP1, and one female fed HP1 being removed from the experiment prior to the start of Phase 2. No chemical analyses were conducted on these animals and their performance data were excluded from any statistical analysis. A possible reason for a higher number of LP1 fed pigs being excluded, was because there were three times more of these pigs than those fed HP1. For the average daily gain (ADG), food intake (FI) and feed conversion efficiency (FCE) the experimental unit was the pen average. For body composition and respective protein and lipid growth rates, an individual pig was the experimental unit. The reason for different experimental units was that food intake of individual pigs in a pen was not recorded, but rather the total group intake and, therefore, food intake was expressed as the pen average food intake per pig. Treatment comparisons were made over equal weight intervals. The results were analysed using the general analysis of variance in Genstat (1997) with foods in Phase 1, foods in Phase 2 and sex as factors. One animal was euthanised due to an internal injury and one died of natural causes.

\section{Results}

No significant differences between sexes across treatments and within phases were observed, hence the data were pooled to increase the number of replications. The chemical composition of the initial group at a live weight of $15 \mathrm{~kg}$ was: Empty body weight (EBW), $14.63 \pm 0.12 \mathrm{~kg}$; protein weight, $2.19 \pm 0.01 \mathrm{~kg}$ and lipid weight, $1.52 \pm 0.15 \mathrm{~kg}$. The effects of the two dietary concentrations of CP (LP1 and HP1) on the ADG, FI and FCE in Phase 1 are shown in Table 2.

Pigs fed HP1 consumed less $(\mathrm{P}<0.05)$ food $(11 \%$ less $)$ and were more efficient $(\mathrm{P}<0.001)$ than those fed LP1. There were no significant differences in ADG between pigs fed LP1 and HP1 foods. The chemical composition of the pigs slaughtered at the end of Phase 1 is shown in Table 3.

As was intended pigs fed LP1 at the end of this phase were fatter $(\mathrm{P}<0.05)$ and had a higher lipid:protein ratio $(\mathrm{P}<0.05)$ than pigs fed HP1 at a similar EBW. In addition, pigs fed LP1 had a lower empty body water weight $(\mathrm{P}<0.05)$. Pigs fed LP1 had $135 \pm 7.4 \mathrm{~g}$ lipid per $\mathrm{kg}$ EBW whereas pigs fed HP1 had a lipid content of $107 \pm 9.8 \mathrm{~g}$ per $\mathrm{kg}$ EBW. No significant differences in protein at $30 \mathrm{~kg}$ live weight and the rate of 
protein retention $(\mathrm{PR})$ were observed between the protein treatments. However, there were differences $(\mathrm{P}<0.05)$ in the LR:PR ratio between the pigs fed HP1 and LP1 foods and, therefore, pigs on LP1 deposited more lipid per unit of protein than those fed HP1 food.

Table 2 The effects of feeding a high (HP1) and low (LP1) crude protein food on average daily gain (ADG), food intake (FI) and food conversion efficiency (FCE) between 15 and 30 live weight

\begin{tabular}{lccc}
\hline Food & $\begin{array}{c}\text { ADG } \\
(\mathrm{kg} / \mathrm{d})\end{array}$ & $\begin{array}{c}\mathrm{FI} \\
(\mathrm{kg} / \mathrm{d})\end{array}$ & $\begin{array}{c}\mathrm{FCE} \\
\text { (kg gain } / \mathrm{kg} \text { food) }\end{array}$ \\
\hline HP1 & 0.597 & 0.963 & 0.623 \\
LP1 & 0.610 & 1.086 & 0.564 \\
s.e.d. & 0.027 & 0.045 & 0.013 \\
Significance & $*$ & $* * *$ \\
$*=\mathrm{P}<0.05$ and $* * *=\mathrm{P}<0.001$ &
\end{tabular}

Table 3 The effects of feeding a high (HP1) and low (LP1) crude protein food on the chemical composition of the empty body weight (EBW) and the respective component to protein ratios of pigs at $30 \mathrm{~kg}$ live weight, and the protein (PR) and lipid (LR) retention rates between 15 and $30 \mathrm{~kg}$ live weight

\begin{tabular}{|c|c|c|c|c|c|c|c|c|}
\hline \multirow[b]{2}{*}{ Food } & \multirow[t]{2}{*}{$\begin{array}{c}\text { EBW } \\
(\mathrm{kg})\end{array}$} & \multicolumn{3}{|c|}{$\begin{array}{l}\text { Component weights } \\
(\mathrm{kg})\end{array}$} & \multicolumn{2}{|c|}{$\begin{array}{c}\text { Growth rates } \\
(\mathrm{g} / \mathrm{d})\end{array}$} & \multicolumn{2}{|c|}{ Ratios } \\
\hline & & Protein & Lipid & Water & PR & LR & Lipid:Protein & LR:PR \\
\hline HP1 & 28.49 & 4.58 & 3.06 & 19.38 & 110 & 74 & 0.67 & 0.67 \\
\hline LP1 & 28.85 & 4.52 & 3.87 & 18.58 & 101 & 103 & 0.86 & 1.02 \\
\hline s.e.d. & 0.55 & 0.11 & 0.33 & 0.28 & 7.0 & 14.8 & 0.08 & 0.14 \\
\hline Significance & & & $*$ & $*$ & & $*$ & $*$ & $*$ \\
\hline
\end{tabular}

Table 4 Treatment effects on average daily gain (ADG), feed conversion efficiency (FCE) and food intake (FI) of pigs given access to a high (HP2), medium (MP2) and low (LP2) crude protein food between 30 and $60 \mathrm{~kg}$ live weight, after a period of being fed a low crude protein (LP1) food between 15 and $30 \mathrm{~kg}$

\begin{tabular}{|c|c|c|c|c|}
\hline \multicolumn{2}{|c|}{ Food } & \multirow{2}{*}{$\begin{array}{l}\mathrm{ADG} \\
(\mathrm{kg} / \mathrm{d})\end{array}$} & \multirow{2}{*}{$\frac{\text { FI }}{(\mathrm{kg} / \mathrm{d})}$} & \multirow{2}{*}{$\frac{\text { FCE }}{(\mathrm{kg} \text { gain } / \mathrm{kg} \text { food })}$} \\
\hline $15-30 \mathrm{~kg}$ & $30-60 \mathrm{~kg}$ & & & \\
\hline HP1 & HP2 & 0.697 & 1.880 & $0.370^{\mathrm{a}}$ \\
\hline LP1 & HP2 & 0.610 & 1.871 & $0.327^{\mathrm{ab}}$ \\
\hline LP1 & MP2 & 0.553 & 1.753 & $0.313^{\mathrm{b}}$ \\
\hline LP1 & LP2 & 0.670 & 2.230 & $0.303^{\mathrm{b}}$ \\
\hline s.e.d. & & 0.071 & 0.289 & 0.022 \\
\hline Significance & & & & $*$ \\
\hline
\end{tabular}

${ }^{\mathrm{a}, \mathrm{b}}$ Means within columns with different superscripts differ significantly; $*=\mathrm{P}<0.05$ 
The main effects of the four feeding treatments on ADG, FI and FCE in Phase 2 are shown in Table 4. Differences $(\mathrm{P}<0.05)$ in FCE were noted between the different feeding regimes although there were no differences in ADG and FI. The response in pigs continuously fed the high protein food (HP1-HP2) and pigs fed LP1-HP2 foods were not different $(\mathrm{P}>0.05)$ from each other. The chemical composition of the slaughtered pigs at $45 \mathrm{~kg}$ live weight and the rates of tissue retention between 30 and $45 \mathrm{~kg}$ are shown in Table 5 .

The only significant difference in composition and rate of retention between foods at $45 \mathrm{~kg}$ live weight was recorded for the rate of lipid retention (LR) and the lipid to protein ratio. Pigs fed HP1-HP2 and LP1-LP2 foods had similar lipid retention rates, which were higher $(\mathrm{P}<0.05)$ than pigs fed LP1-HP2 and LP1-MP2 foods. Pigs previously fed the LP1 food but fed HP2 after $30 \mathrm{~kg}$, deposited the least lipid, with pigs fed LP1-MP2 depositing an amount of lipid almost half way between pigs fed LP1-HP2 and LP1-LP2. The lipid:protein ratios between CP foods were not significantly different. The response in the LR:PR ratio to dietary CP content during Phase 2 was similar to that observed in LR.

Table 5 The effects of feeding an initial high (HP1) and low (LP1) crude protein food between 15 and $30 \mathrm{~kg}$ on the chemical composition of the empty body weight (EBW) and the respective component to protein ratios at 45 $\mathrm{kg}$ live weight, and the protein (PR) and lipid (LR) retention rates between 30 and $45 \mathrm{~kg}$ live weight in pigs given access to a high (HP2), medium (MP2) and low (LP2) protein food

\begin{tabular}{|c|c|c|c|c|c|c|c|c|c|}
\hline \multicolumn{2}{|c|}{ Treatment } & \multirow[t]{2}{*}{$\begin{array}{c}\text { EBW } \\
(\mathrm{kg})\end{array}$} & \multicolumn{3}{|c|}{$\begin{array}{l}\text { Component weights } \\
(\mathrm{kg})\end{array}$} & \multicolumn{2}{|c|}{$\begin{array}{l}\text { Growth rates } \\
(\mathrm{g} / \mathrm{d})\end{array}$} & \multicolumn{2}{|c|}{ Ratios } \\
\hline $15-30 \mathrm{~kg}$ & $30-45 \mathrm{~kg}$ & & Protein & Lipid & Water & PR & LR & Lipid:Protein & LR:PR \\
\hline HP1 & HP2 & 43.79 & 7.38 & 5.84 & 28.09 & 140 & $119^{\mathrm{a}}$ & 0.79 & $0.85^{\mathrm{ac}}$ \\
\hline LP1 & HP2 & 42.49 & 7.32 & 5.28 & 27.62 & 131 & $49^{\mathrm{b}}$ & 0.72 & $0.38^{\mathrm{b}}$ \\
\hline LP1 & MP2 & 43.83 & 7.48 & 6.16 & 27.86 & 112 & $78^{\mathrm{c}}$ & 0.82 & $0.69^{c}$ \\
\hline LP1 & LP2 & 42.82 & 7.16 & 6.34 & 26.85 & 115 & $122^{\mathrm{a}}$ & 0.89 & $1.06^{\mathrm{a}}$ \\
\hline \multicolumn{2}{|l|}{ s.e.d. } & 0.78 & 0.21 & 0.51 & 0.92 & 15.1 & 7.7 & 0.08 & 0.16 \\
\hline \multicolumn{2}{|c|}{ Significance } & & & & & & $* * *$ & & $* *$ \\
\hline
\end{tabular}

$\overline{a, b, c}$ Means within columns with different superscripts differ significantly; $* *=\mathrm{P}<0.01$ and $* * *=\mathrm{P}<0.001$

The chemical composition and intakes of protein and lipid retention of pigs between 45 and $60 \mathrm{~kg}$ live weight are shown in Table 6 . At $60 \mathrm{~kg}$ live weight, protein weight of pigs fed the MP2 food was higher $(\mathrm{P}<$ 0.05 ) than pigs fed any of the remaining foods, but the rate of protein deposition was not significant. The opposite trend occurred with lipid, where no significant differences in the lipid weight at $60 \mathrm{~kg}$ were observed between pigs on different $\mathrm{CP}$ foods but there were differences $(\mathrm{P}<0.05)$ in LR between 45 and $60 \mathrm{~kg}$ live weight. Pigs fed low CP diets continuously, had the highest LR. A similar response was observed in the lipid:protein ratio.

\section{Discussion}

According to Stamataris et al. (1991) and Kyriazakis \& Emmans (1991), if pigs are maintained in an ideal environment and fed a non limiting food they retain protein and lipid at their genetic capacity, which they also define as the normal rate of growth. As the high CP foods (HP1 and HP2) were formulated to satisfy the protein requirements during the respective phases, the rate and composition of growth in pigs fed the high CP foods throughout the experiment were assumed to be close to their normal levels of growth. The relevance of Phase 1 was to create two groups of pigs with varying levels of body lipid. Pigs fed LP1 had $26 \%$ more lipid in the empty body than those fed HP1, which were assumed to have normal levels of protein and lipid. Kyriazakis \& Emmans (1991; 1992), Kyriazakis et al. (1991) and Ferguson \& Gous (1997) showed how pigs fed lower CP diets, with similar energy levels, attempted to satisfy their requirements for normal protein retention by consuming more food. However, the consequence was an oversupply of energy and an increase in lipid 
retention. A similar result was observed in this experiment, where higher rates of lipid retention, associated with similar protein retention rates were reported in pigs fed LP1 compared to HP1. The slight (11\%) improvement in FCE in pigs fed the HP1 food suggests that these pigs could attain their normal protein growth rate on a lower FI, compared with those pigs fed LP1. The higher intakes, and subsequent faster LR, observed in pigs fed LP1 did not significantly increase live weight growth rates, but did ensure that PR between foods were similar. A consequence of this response is that the lipid:protein ratio of the empty body was significantly higher in pigs fed LP1 than HP1 food. Similar results were obtained by Kyriazakis \& Emmans (1991), Ferguson \& Gous (1997) and Ferguson et al. (2000).

Table 6 The effects of feeding an initial high (HP1) and low (LP1) crude protein food between 15 and $30 \mathrm{~kg}$ on the chemical composition of the empty body weight (EBW) and the respective component to protein ratios at 60 $\mathrm{kg}$ live weight, and the protein (PR) and lipid (LR) retention rates between 45 and $60 \mathrm{~kg}$ live weight in pigs given access to a high (HP2), medium (MP2) and low (LP2) crude protein food

\begin{tabular}{lccccccccc}
\hline \multicolumn{2}{c}{ Treatment } & $\begin{array}{c}\text { EBW } \\
(\mathrm{kg})\end{array}$ & \multicolumn{2}{c}{$\begin{array}{c}\text { Component weights } \\
(\mathrm{kg})\end{array}$} & \multicolumn{2}{c}{$\begin{array}{c}\text { Growth rates } \\
(\mathrm{g} / \mathrm{d})\end{array}$} & \multicolumn{2}{c}{ Ratios } \\
\hline 15-30kg & 30-60kg & & Protein & Lipid & Water & PR & LR & Lipid:Protein & LR:PR \\
HP1 & HP2 & 56.83 & $9.15^{\mathrm{a}}$ & 7.84 & 36.16 & 114 & $119^{\mathrm{a}}$ & $0.86^{\mathrm{a}}$ & 1.04 \\
LP1 & HP2 & 57.75 & $9.32^{\mathrm{a}}$ & 8.34 & 36.73 & 113 & $137^{\mathrm{ab}}$ & $0.89^{\mathrm{a}}$ & 1.21 \\
LP1 & MP2 & 56.20 & $9.79^{\mathrm{b}}$ & 7.70 & 35.58 & 127 & $113^{\mathrm{a}}$ & $0.79^{\mathrm{a}}$ & 0.88 \\
LP1 & LP2 & 57.41 & $9.32^{\mathrm{a}}$ & 9.66 & 35.35 & 125 & $174^{\mathrm{b}}$ & $1.04^{\mathrm{b}}$ & 1.39 \\
s.e.d. & & 0.98 & 0.19 & 1.12 & 1.32 & 15.0 & 18.1 & 0.081 & 0.6 \\
\multicolumn{2}{l}{ Significance } & & $*$ & & & & $*$ & $*$ & $*$ \\
\hline
\end{tabular}

${ }^{\mathrm{a}, \mathrm{b}}$ Means within columns with different superscripts differ significantly; $*=\mathrm{P}<0.05$

Pigs fed a high CP diet after a period of excess fattening (treatment LP1-HP2), deposited lipid at a rate less than half that of those pigs maintained on the high CP food. Similarly, pigs fed MP2 deposited less lipid (0.66 times less) than those fed HP1-HP2. Pigs fed LP1-LP2 had similar LR as pigs fed HP1-HP2. These results suggest that with the addition of only $15 \mathrm{~kg}$ in live weight, pigs that were fatter had fully compensated by depositing less lipid and had a similar body composition as those not fed a nutritionally limiting food - where a nutritionally limiting food is defined as a food that will cause the body composition of the animal eating the food to deviate from its potential composition. In this case, dietary protein was the limiting factor. Given that they were growing at $0.610 \pm 0.049 \mathrm{~kg} / \mathrm{d}$, this rehabilitation occurred over a period of approximately 25 days. Although FI and ADG in previously fat pigs were not significantly different when fed HP2, MP2 or LP2, the rate of lipid retention in pigs fed HP2 was significantly lower than those fed LP2 or MP2 (49 vs 78 or $122 \mathrm{~g} / \mathrm{d}$ ).

Between 45 and $60 \mathrm{~kg}$ live weight, LR between foods changed with pigs fed LP1-LP2 depositing more lipid compared with pigs fed HP1-HP2. However, LR responses between foods HP1-HP2, LP1-HP2 and LP1MP2 were similar, although pigs fed LP1-HP2 retained more lipid. The similarity in LR responses between these treatments may suggest that compensation was completed by $45 \mathrm{~kg}$.

It could be argued that any pig, irrespective of its current level of fatness, fed a high CP food will retain less lipid than animals fed a low CP food as the animal is less likely to over consume energy. However, in this experiment, pigs that were continuously fed a high CP food (HP1-HP2), and, therefore, assumed to be growing protein and lipid tissue according to their target, had a significantly higher LR than rehabilitating, fatter pigs fed the same high CP food. Similar results were observed in the ratio of lipid:protein weight, where pigs fed LP1 had a higher lipid:protein weight ratio than those pigs fed HP1 at the end of the fattening phase $(30 \mathrm{~kg})$. However, when the pigs fed the LP1 food were fed HP2, the lipid:protein ratio decreased to a similar level as to those pigs that had been fed only the high CP foods. These results dismiss the proposition that the current state of the animal, as defined by its lipid and protein content, has no effect on the subsequent rates of tissue retention. Likewise, pigs with a higher body lipid content at $30 \mathrm{~kg}$, and then fed HP2, had significantly lower LR between 
30 and $45 \mathrm{~kg}$ than leaner pigs. By $45 \mathrm{~kg}$ this difference in lipid content had disappeared and so did the differences in LR between 45 and $60 \mathrm{~kg}$. The weight of water in the empty body followed a similar but inverse response as body lipid. Fatter pigs fed MP2 also appeared to adjust their LR to achieve a similar body lipid content as the leaner pigs. Pigs not afforded the opportunity to rectify their current state (e.g. pigs fed only a low CP food) consistently deposited more lipid. These findings support (or at least don't contradict) the theory that pigs do attempt to return to a normal level of fatness, as defined by the lipid content of those pigs fed a nonlimiting food, when the source of the problem is removed.

According to Whittemore (1998), the level of fatness an animal would desire to attain, is that which minimises the cost of metabolism while partitioning and prioritising available nutrients toward meeting its potential lean tissue growth. This implies that, when animals become excessively fat and are given the opportunity (e.g. high quality diet), they will utilize the excess body fat to sustain normal protein growth at the expense of dietary sources of energy and/or they will deposit less lipid to restore the lipid:protein ratio. The exact nature of the rehabilitating response will depend on the extent of the excessive body lipid and the protein:energy ratio of the food (Kyriazakis et al., 1991). The larger the deviation from normal lipid growth the more likely the excess body lipid will be catabolised and used for production purposes, and particularly if the dietary protein:energy ratio is high. In this experiment, previously fatter pigs reduced their rate of lipid retention rather than lose body lipid, while protein retention was maintained at the normal rate, during the compensatory period. This compensation continued until the animals appeared to reach levels of lipid that were similar to those of pigs fed HP2. Kyriazakis \& Emmans (1991) observed a similar response in young pigs but ended the experiment before the animals were able to utilize all their excess lipid. The minimum LR:PR during this rehabilitation process is uncertain although evidence from this experiment and those of Kyriazakis \& Emmans (1991) and Kyriazakis et al. (1991) suggested a minimum range of between 0.29 and 0.38 .

The significantly higher body protein weight at $60 \mathrm{~kg}$, observed in pigs fed LP1-MP2 foods is probably due to the combination of a higher body protein weight at $45 \mathrm{~kg}$ and a higher PR between 45 and $60 \mathrm{~kg}$. Although both these responses were not significantly higher than the responses of the other foods, when combined they resulted in an increased body protein weight.

\section{Conclusion}

The results of this experiment confirmed the postulations of Kyriazakis \& Emmans (1992) that pigs made fatter than animals grown under non-limiting conditions will attempt to rectify this "abnormal" state by reducing their rate of lipid retention when the cause of the fattening is eliminated. This would continue until they return to similar lipid:protein ratios, or similar body lipid weights, as animals that have grown uninhibited. During this period of rehabilitation the minimum LR:PR ratio can decrease to as low as 0.38 .

\section{Acknowledgments}

The authors wish to thank the staff at the pig section of the University Research farm, D. Davies, M. Ferreira, M Hundley and S Opperman for their technical assistance. This work was supported by grants from the Protein Research Trust and University of Natal Research Fund.

\section{References}

AOAC, 1984. Official methods of analysis. (14th ed.). Association of Official Analytical Chemists, Inc., Washington, DC.

Campbell, R.G. \& Biden, R.S., 1978. The effect of protein nutrition between 5.5 and $20 \mathrm{~kg}$ live weight on the subsequent performance and carcass quality of pigs. Anim. Prod. 27, 223-228.

Campbell, R.G. \& Dunkin, A.C., 1983. The influence of protein nutrition in early life on growth and development of the pig. 1. Effects on growth performance and body composition. Br. J. Nutr. 50, 605617.

Emmans, G.C., 1981. A model of the growth and feed intake of ad libitum fed animals, particularly poultry. In: Computers in Animal Production, Br. Soc. Anim. Prod. Occ. Publ. No. 5. pp. 103-110.

Emmans, G.C. \& Kyriazakis, I., 1999. Growth and body composition. In: A Quantitative Biology of the Pig. Ed. Kyriazakis, I., CABI Publishing, Wallingford, UK. pp. 181-197. 
Ferguson, N.S. \& Gous, R.M., 1997. The influence of heat production on voluntary food intake in growing pigs given protein - deficient diets. Anim. Sci. 64, 365 - 378.

Ferguson, N.S., Arnold, G.A., Lavers, G. \& Gous, R.M., 2000. The response of growing pigs to amino acids as influenced by environmental temperature. 1. Threonine. Anim. Sci. 70, 287-297.

Ferguson, N.S., Lavers, G. \& Gous, R.M., 2001. The effect of stocking density on the responses of growing pigs to dietary lysine. Anim. Sci. 73, 459-469.

Genstat, 1997. Genstat 5 (Release 5.1) Committee of the Statistic Department, Rothamsted Experimental Station. Oxford, Clarendon Press.

Kielanowski, S., 1969. Energy and protein metabolism in growing pigs. Rev. Cubana Ciencia Agric. 3, 207-216.

Kyriazakis, I. \& Emmans, G.C., 1991. Diet selection in pigs: Dietary choices made by growing pigs following a period of underfeeding with protein. Anim. Prod. 52, 337-346.

Kyriazakis, I. \& Emmans, G.C., 1992. The growth of mammals following a period of nutritional limitation. J. Theor. Biol. 156, 485-498.

Kyriazakis, I., Stamataris, C., Emmans, G.C. \& Whittemore, C.T., 1991. The effects of food protein content on the performance of pigs previously given foods with low or moderate protein contents. Anim. Prod. 52, 165-173.

Moughan, P.J., 1999. Protein metabolism in the growing pig. In: A Quantitative Biology of the Pig. Ed. Kyriazakis, I., CABI Publishing, Wallingford, UK. pp. 299-332.

Schinckel, A.P., 2001. Nutrient requirements of modern pig genotypes. In: Recent Developments in Pig Nutrition 3. Eds. Wiseman, J. \& Garndworthy, P.C., Nottingham University Press, Nottingham, UK. pp. 399-438.

Stamataris, C., Kyriazakis, I. \& Emmans, G.C., 1991. The performance and body composition of young pigs following a period of growth retardation by food restriction. Anim. Prod. 53, 373-381.

Tullis, J.B. and Whittemore, C.T., 1986. Body composition and feed intake of young pigs postweaning. J. Sci Food Agric. 37, 1178-1184.

Wang, T.C. \& Fuller, M.F., 1989. The optimum dietary amino acid pattern for growing pig. 1. Experiments by amino acid deletion. Br. J. Nutr. 62, 77-89.

Whittemore, C.T., 1993. The Science and Practice of Pig Production. Longman Scientific and Technical, Essex, UK.

Whittemore, C.T., 1998. The Science and Practice of Pig Production, $2^{\text {nd }}$ ed. Blackwell Science Ltd., Oxford.

Whittemore, C.T., Tullis, J.B. \& Emmans, G.C., 1988. Protein growth in pigs. Anim. Prod. 46, 437-445.

Wilson, P.N. \& Osbourn, D.F., 1960. Compensatory growth after under nutrition in mammals and birds. Biol. Rev. 35, 324-363. 